\title{
ANTIBIOTIC RESISTANCE OF MYCOBACTERIUM TUBERCULOSIS; MECHANISMS AND SPECIFIC THERAPEUTIC RESPONSE
}

\author{
GILDA GEORGETA POPESCU ${ }^{1}$, OANA CRISTINA ARGHIR ${ }^{2}$, ARIADNA PETRONELA FILDAN ${ }^{2}$, \\ VICTOR SPANU $^{1}$, SIMONA CLAUDIA CAMBREA ${ }^{2}$, ALEXANDRU RAFILA ${ }^{3 *}$, FLORIN \\ CORNELIU BUICU ${ }^{4}$
}

\author{
1 "Marius Nasta” Pneumonology Institute, Bucharest, Romania \\ 2 "Ovidius" University, Faculty of Medicine, Constanța, Romania \\ 3 "Carol Davila" University of Medicine and Pharmacy, Bucharest, Romania \\ ${ }^{4}$ University of Medicine, Pharmacy, Science and Technology, Târgu-Mureș, Romania
}

*corresponding author: arafila@yahoo.com

\begin{abstract}
Although epidemiologic indicators of tuberculosis (TB) are rapidly improving in Romania, the disease remains a high priority of the public health. In the last years, the World Health Organization (WHO) has paid particular attention to the phenomenon of multidrug resistant tuberculosis (MDR-TB), which Romania is not exempt from. As an endemic, TB has a long history. In the evolution of this disease, the etiological treatment had a later appearance, but the drug resistance phenomenon, acting as selection pressor, was highlighted from the beginning. The advanced knowledge of the drug resistance mechanisms, early imposed the idea of drug combination. The history of the development and use of chemotherapeutic agents in the treatment of TB demonstrates the difficulty in obtaining strong resilience of the therapeutic regimens and the increased risk of unsuccessful outcomes, due to the drug resistance phenomenon. Expanding the global response to MDR-TB is relatively recent, only the last two decades, but the progress has been substantial. The latest WHO guidelines for MDR-TB therapy is a "game-changer". This article updates the new classification of anti-TB drugs by classes, their characteristics and place in the therapeutic regimes, but also the recommendations and challenges for their application.
\end{abstract}

\section{Rezumat}

Deși indicatorii epidemiologici ai tuberculozei se îmbunătățesc rapid în România, tuberculoza rămâne o problemă prioritară de sănătate publică. În ultimii ani, Organizația Mondială a Sănătății (OMS) acordă o atenţie deosebită tuberculozei multidrog rezistente (TB-MDR), de la care nici România nu este exceptată. Ca endemie, tuberculoza are o evoluție lungă. Tratamentul etiologic a apărut târziu în istoria acestei maladii, însă fenomenul rezistenței la antibiotice, care funcționează ca presor de selecție, a fost pus în evidență încă de la început. Înțelegerea mai aprofundată a mecanismelor apariției a chimiorezistenței a impus încă de timpuriu ideea terapiei asociate. Istoria descoperirii și utilizării chimioterapicelor în tratamentul TB-MDR demonstrează cât este de dificilă stabilizarea regimurilor terapeutice și cât de periculoasă pentru controlul bolii este emergența multirezistenței. Dezvoltarea răspunsului global la problemă este de dată relativ recentă, circa două decenii, dar progresele sunt substanțiale. Ultimele ghiduri ale OMS dedicate terapiei TB-MDR, sunt un "game-changer". Articolul prezintă noua clasificare a medicamentelor antituberculoase, caracteristicile și poziția lor în schemele terapeutice, precum şi recomandări și provocări ale administrării lor.

Keywords: endemic TB, chemotherapeutic pathogenesis, anti-TB drugs

\section{Introduction}

The reorganization on a modern basis of the Romanian tuberculosis (TB) control network was possible, after implementation of the Directly Observed Treatment (DOT) strategy after 1989, as a result of the recommendations of WHO. The treatment-related favourable endemic dynamics is illustrated by the downward curve of incidence between 1972 and 2018 which registers a decrease of $58.6 \%$, from the maximum level of $142.9 \%$ registered in 2002 to $59.1 \%$ registered in 2018 (Figure 1).

The major achievement of the strategy has been demonstrated by the improvement of ranking of Romania on European TB incidence map. Starting from the $3^{\text {rd }}$ place, Romania now ranks on the $7^{\text {th }}$ place on the European Region of WHO, after Kazakhstan, Republic of Moldova, Georgia, Kyrgyzstan, Turkmenistan, Tajikistan, but still keeping the first place among the European Union countries [1].

In recent years, WHO have given a particular consideration to the chemoresistance phenomenon, setting out a series of recommendations aimed to control the spread of the TB infection resistant to anti-tuberculosis drugs. Despite the decrease of the cases of MDR-TB from 792 to 353 (2008 to 2009), this remains a major public health problem in Romania (Figure 2). 


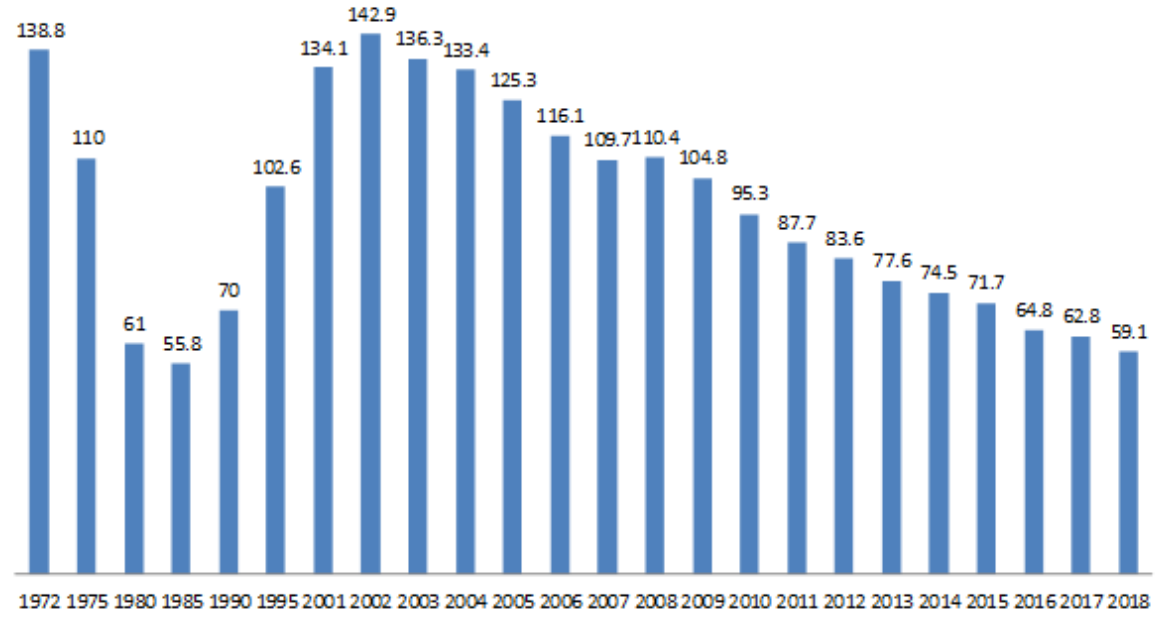

Figure 1.

TB Incidence - Romania 1972 - 2018, \%000

Source: National database for TB (updated June 2019)

MDR-TB $\square$ XDR-TB

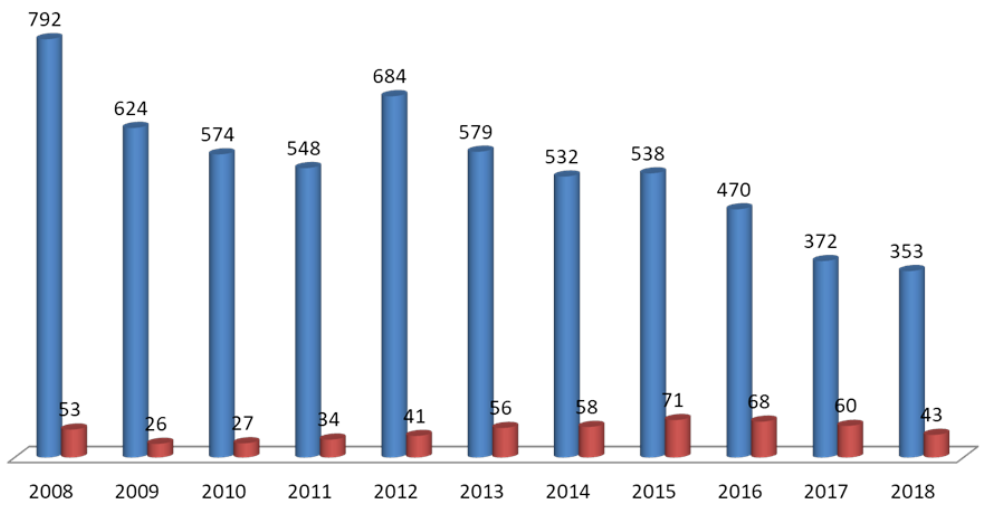

Figure 2.

Number of MDR/XDR-TB cases in Romania (2008 - 2018)

Source: National database for TB (updated June 2019)

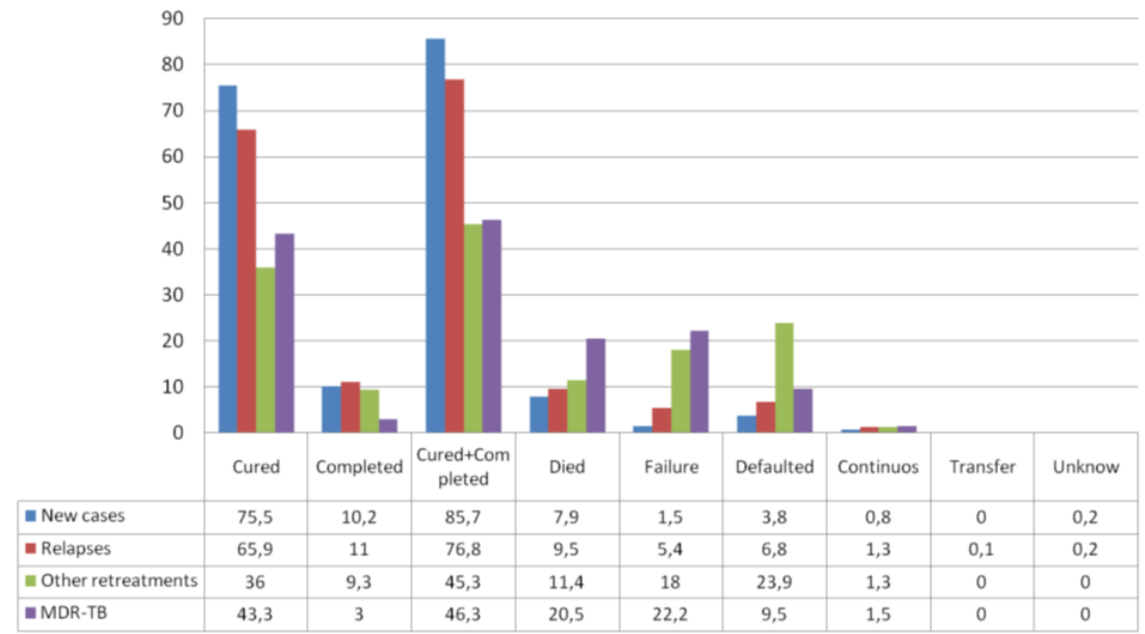

Figure 3.

Results of TB treatment of confirmed pulmonary cases (2017) and MDR-TB pulmonary cases (2016) - \% Source: National database for TB

In a retrospective manner, we have reviewed the surveillance and control of MDR-TB in Romania, as a long-term process, which has been considered with relative scepticism in its early days, but it is 
now the focus of a more optimistic consideration, with a therapeutic success rate steadily increasing. In 2016 it was registered a success rate of $46.3 \%$, meaning almost an increase of 3 times from the 2018 cohort, which was $16.8 \%$. Solving the current public health problem will only be possible through the joint effort of all those involved in tuberculosis control (Figure 3).

\section{Evolution}

The tuberculosis endemic has had a long history. Statistical models (Grigg) suggest a particular dynamic of the disease in a community, expressed by a growing trend, leading to a peak of incidence and mortality, and then followed by progressive attenuation, spontaneous and continued over centuries. Due of this model of evolution, the specific diagnosis of TB through bacteriological and imagistic techniques, as well as etiological treatment, appeared lately in the evolution of endemic, beginning with the end of $19^{\text {th }}$ century. The facts of discovery and usage of penicillin, in early 40', had no effect on M. tuberculosis, but encouraged Selman Waksman's research, and then lead to Albert Schatz's discovery of streptomycin (SM) in 1949, which was the first antibiotic with anti-TB action proved by initial clinical trials [2]. The most relevant of these trials was "Streptomycin treatment of pulmonary tuberculosis" published in 1948 by the Medical Research Council, United Kingdom, which was the first randomized controlled study in history. It demonstrated the favourable, sometimes temporary, effect of SM, but also revealed the occurrence of bacterial resistance and induced adverse reactions [3].

The detailed analysis of $M$. tuberculosis resistance to streptomycin began with the work of Pyle, Mitchison, Youmans, Kekaku and others. Soon, the idea of controlling the phenomenon by associating a second antibiotic to the therapy had occurred [4].

The first targeted anti-TB chemotherapic had been synthesized by Lehmann, based on the knowledge that salicylate influence mycobacterial metabolism. This drug, PAS (para-amino salicylic acid), was synthesized in the same time when streptomycin was discovered, in 1943. There were evaluations that put doubts to the clinical response to PAS, due to the bacteriostasis it had induced.

Another remarkable study endorsed by the same British Medical Research Council (BMRC) in 1949, reproducing the randomization and control group methodology already used in streptomycin trials, associated PAS and SM for the first time. The combination was compared with their administration as monotherapy. While SM alone induced resistance in $70 \%$ of patients, association with PAS decreased the percentage to $9 \%$ [5].

In 1951, through a useful coincidence, three pharmaceutical companies discovered the anti-TB action of isoniazid (INH). Based on the model established in 1948,
BMRC clinically validated the drug in 1952, highlighting the high resistance rate induced by monotherapy $(71 \%$ at 3 months) [6].

Once again, the idea of drug association was successful. The era of "triple therapy" represented by INH, SM, and PAS started and remained the basis of anti-TB treatment for the next 15 years.

In the following years, important discoveries were made, such as pyrazinamide (PZM) (1952), ethambutol (EMB) (1961) and rifampicin (RMP) (1967) and many clinical trials evaluated the proper indication of each drug in the therapeutic regimens, regarding dosages, rate of administration, duration of treatment, and later the need for administration under direct observation. The intralesional germ populations, the intra- and extramacrophagic action of anti-TB antibiotics, bactericidal and sterilizing effects, minimal inhibitory concentration values, therapeutic coefficients and post-therapy effects were demonstrated and defined, setting the foundation of modern therapy [7].

The combination of isoniazid, rifampicin, pyrazinamide and ethambutol, used to treat drug susceptible TB, is still unsurpassed regarding their therapeutic value, even if the ideal treatment is yet to be discovered. The resistance phenomenon has accompanied antiTB therapy from the very beginning. In severe MDR cases, with resistance at least to isoniazid and rifampicin, the incidence was 600,000 cases per year and produced 230,000 deaths annually [1].

For a long time, treatment of drug resistant TB (DRTB) has not been a priority in national programs with limited resources. Since 1997, the theoretical bases of DR-TB therapy have been established and a widerange of institutional and organizational processes has been initiated by the World Health Organization, which has gradually improved the access to individualized treatment. Currently one third of the patients with DR-TB are treated as required, according to international guidelines, which emphasizes the magnitude of the problem [9, 22].

"Second line" drugs used to treat DR-TB, called as such to be distinguished from the "first line" drugs which are used to treat the susceptible strains of $M$. tuberculosis, are more expensive, difficult to obtain and with severe side effects, often used as "off label" products.

Their origin is different, whether they have been evaluated as anti-tuberculosis drugs, but did not prove their efficacy from the perspective of standardized schedules or have been synthesized for other indications, but their effectiveness on $M$. tuberculosis has been observed. Decades later, and for the very first time in 2000, specifically anti-TB molecules, such as delamanid and bedaquiline, were synthesized. These drugs underwent clinical assessment and found a proper place within the TB treatment schedule. 
FARMACIA, 2020, Vol. 68, 2

\section{Causes of the emergence and dissemination of drug} resistant mycobacteria

Scientists recognized the emergence of resistant strains immediately after the introduction of anti-tuberculosis therapy. Pyle et al. described the emergence of drug resistance during Streptomycin treatment in 1947 [10]. In the ' 50 s, researchers showed the presence of drugresistant bacilli from wild strains of Mycobacterium tuberculosis, even before exposure to any drug. Some strains, resistant to isoniazid showed a reduced catalase activity, but the molecular basis of resistance have been unknown for a long time.

In 1970, David et al. demonstrated that drug resistance occurs through spontaneous and random mutations in the bacterial chromosome. They calculated the average rate of mutations to isoniazid, rifampicin, etambutol and streptomycin, as well as the highest proportion of possible mutation in the non-selected populations of M. tuberculosis for each drug. The mutation rate for M. tuberculosis resistance to INH was $2.56 \times 10^{-8}$ mutations per bacterium in one generation; for RMP of $2.25 \times 10^{-10}$; for EMB of $1.0 \times 10^{-7}$ and for $\mathrm{SM}$ of $2.95 \times 10^{-8}$. The estimated ratio between resistant and susceptible bacilli in an unselected $M$. tuberculosis population was $1: 10^{6}$ for both INH and SM, $1: 10^{5}$ for EMB and $1: 10^{8}$ for RMP [11].

The probability of occurrence of more than one drug chemoresistance is calculated by multiplying the mutation rates for each drug. Therefore, resistant bacilli to both INH and RMP are expected to occur less than once in an unselected population of $10^{14}$ bacilli. Because lung cavities contain between $10^{7}$ to $10^{9}$ bacilli, they may contain a small number of resistant bacilli on each of the antituberculous drugs, but are unlikely to contain resistant bacilli for two drugs at the same time.

Generally, the emergence of drug resistance depends on: the mycobacterial type, with faster emergence for M. bovis and atypical mycobacteria; the initial proportion of resistant mutants, with faster development in higher proportions; the magnitude of mycobacterial population (more mutants resistant to a larger mycobacterial population); the type of metabolism for some antituberculous drugs (the resistance appears slower to the rapid isoniazid inactivators); the anatomical type of tuberculous lesion (the emergence of resistance is faster for cavity lesions); the type of regimens and the accuracy of drug administration (one of the most important factors).

Drug-resistant tuberculosis occurs if, from the total infectious bacterial population, resistant bacilli multiply in excess, compared to drug susceptible bacilli, due to the selection and multiplication of resistant strains through inadequate treatment. This will occur early during treatment, if the bacterial population is numerous and only one drug is used to treat tuberculosis.

During the initial phase of the treatment, if only one drug is used, most drug-sensitive bacilli are destroyed, and the number of bacilli from sputum rapidly decreases, while resistant germs multiply unaffected. In a period from two weeks to several months, drug resistance bacilli will be more numerous than those susceptible. The sputum count of mycobacteria will increase again, and the clinical form of resistance to treatment will become evident. This process is known as the "fall and rise" phenomenon (decrease and then multiplication) [12]. In a large population of resistant bacilli, additional mutations can also occur, resulting in the emergence of resistant mutants (selective pressors) to two drugs. The major causes of the development and spread of drug resistance are the poor compliance with the prescribed treatment, the use of inadequate treatment regimens, delayed diagnosis and treatment or inadequate isolation conditions. If drugs are not taken as prescribed and bacilli are exposed to a single drug for longer periods of time, multiplication of drug resistant germs may occur.

In addition, in some treatment regimens which contain more than one drug, the germs are susceptible only to one of them. These regimens are equivalent to monotherapy and may have as result the selection of multidrug resistant germs. Acquired multidrug resistance usually results through a combination of lack of compliance with inappropriate treatment.

Obviously, the emergence of chemo-resistant bacilli can be avoided with the appropriate therapy with multiple drugs in different combinations. Combined regimens are the most important in the initial phase of treatment, when the bacilli population is the most abundant. Anti-tuberculosis medication varies in terms of ability to prevent resistance to other drugs, isoniazid (INH) and rifampicin (RMP) showing most effectiveness. The occurrence of chemoresistance is less likely in most cases of extra-pulmonary TB, where the population of bacilli is much smaller. Since the bacilli population is lower in latent TB infection, the risk of secondary resistance to previously treated patients is negligible, even with monotherapy. A study of Nolan et al. supports this observation. Patients with latent TB infection, who received preventive treatment with INH for 3 months or less, had a 6 times higher risk to develop a INH-sensitive active TB, but didn't have a higher risk for INH-resistant TB, compared with those who received preventive treatment for $6-12$ months [13].

\section{Classification of resistance to TB drugs. Definitions.}

The population of $M$. tuberculosis is considered to be resistant if $1 \%$ or more of the microorganisms are resistant to a specific drug concentration, as long as the bacilli have not previously been exposed to any drug. Drug resistant tuberculosis includes the case of $\mathrm{TB}$, usually pulmonary, with bacilli that are resistant to one or more anti-TB drugs [14]. 
The term mono-resistance is used when a strain is resistant to one of the four essential anti-TB drugs; the resistance to more than one drug is considered poly-resistance; multidrug resistance (MDR) appears if the strain is unresponsive simultaneously to at least INH and RMP. MDR- TB is associated with a much higher rate of treatment failure. Although the proportion of MDR-TB within the total number of drug resistant tuberculosis is high, the main priority should not be the treatment, but the prevention of such cases [14]. Drug resistant TB is divided into two types, according to appearance: primary and acquired resistance.

Primary resistance occurs in people who have never been treated for TB; these people are infected with resistant micro-organisms. Because it is difficult to find if the patient has previously received anti-TB treatment, sometimes the term initial resistance is used instead of primary resistance. Its prevalence is increasing in countries with ineffective control programs, and where the directly observed therapy is not well organized. Acquired resistance occurs during TB treatment, either because the patient has been treated with an inadequate regimen or because he has not been compliant to the treatment plan. This definition is accepted if there is the evidence of initial susceptibility to standard drugs. It has been demonstrated that acquired resistance appears to patients who received anti-TB treatment for at least one month.

There are significant differences between primary and acquired resistance, when analysing severity and prevalence criteria [14]: the frequency of primary resistance is lower than the frequency of acquired resistance $(5 \%$ or less in countries with effective antiTB programs and at least $15 \%$ in countries with recently implemented programs); primary resistance is less severe: it is most often a mono-resistance (to $\mathrm{SM}$ or INH) and only exceptionally a triple resistance or multi-resistance, whereas the acquired resistance usually involves two or more drugs; the level of "in vitro" resistance is lower for primary resistance.

For these reasons it is considered that primary resistance affects only little the outcome of the worldwide usage of the standardized regimens [14].

The categories of patients with a higher risk of developing drug resistant TB are represented by: people who have previously received anti-TB treatment; close contacts of people known with drug-resistant TB [15]; people born in areas with a high prevalence of polyresistance (e.g. Latin America, Asia, Africa); patients whose smears and cultures remain positive after 3 months of anti-TB treatment.

Anti-TB drugs: mechanisms of action. The molecular basis of drug-resistance.

Polyresistant strains of $M$. tuberculosis have already spread throughout the world. In many countries and regions, these resistant strains are a serious threat to the effectiveness of TB control programs.

An important element in controlling the TB epidemic is the understanding of the molecular basis of resistance to the most important anti-TB drugs, so more accurate laboratory tests and more appropriate therapeutic regimens may be developed [16-18].

M. tuberculosis and other members of the Mycobacterium complex use several strategies to withstand the action of antimicrobial agents. The mycobacterial cell is surrounded by a highly hydrophobic specialized wall, which leads to a decreased permeability to many compounds.

Recent discoveries have been made regarding active drug penetration systems, enzymes of degradation and inactivation, as well as genes that are associated with these functions. Thus, genetic studies have shown that the resistance of $M$. tuberculosis to antimicrobial drugs is the consequence of spontaneous mutations occurring in the genes encoding the target of the drug or in the enzymes involved in its activation $[19,20]$. Point mutations causing drug-resistance, such as deletions or insertions, for all first-line agents (isoniazid, rifampicin, pyrazinamide, ethambutol and streptomycin) as well as for several second-line agents, some more recently discovered (ethionamide, fluoroquinolones, macrolides, nitro-imidasopyranes) have been described [17].

Today is considered that not only one genetic alteration has implications for the MDR phenotype. Rather, MDR develops through sequential acquisition of mutations at different sites, a common consequence of inappropriate treatment. Because MDR strains are the result of cumulative mutations, the development of M. tuberculosis in the host can be successfully controlled by simultaneous treatment with multiple drugs. Thus, therapeutic regimens with 5 or 6 drugs are commonly used for the treatment of patients with MDR-TB [8, 21, 22].

\section{Therapy of DR-TB. Classes of drugs.}

The main categories of medicines used in tuberculosis treatment are: first line medication, which represents the standard regimen used to treat drug susceptible TB forms; second line medication, which refers to drugs that have not been included in the first-intention schedule, but which are effective in drug-resistant $\mathrm{TB}$ cases (DR-TB).

Since 2006, it has been suggested to group drugs with known anti-TB action. This is not a classification based on their chemical characteristics, but rather on their therapeutic relevance and reason of inclusion in the therapeutic schemes. [23] Currently, based on WHO principle of "Rapid Communication on DR-TB treatment", the medicines are grouped in three categories, based on the efficiency/safety balance (Table I). 
Group of drugs used in MDR-TB therapy

\begin{tabular}{|c|c|}
\hline GROUP & DRUG \\
\hline \multirow{3}{*}{$\begin{array}{l}\text { Group A: } \\
\text { Include all three medicines (unless they cannot be used) }\end{array}$} & levofloxacin $(L F X)$ or moxifloxacin $(M F X)$ \\
\hline & bedaquiline $(B D Q)$ \\
\hline & linezolid (LZD) \\
\hline \multirow{2}{*}{$\begin{array}{l}\text { Group B: } \\
\text { Add both medicines (unless they cannot be used) }\end{array}$} & clofazimine $(C F Z)$ \\
\hline & cycloserine $(C S)$ or terizidone (TRD) \\
\hline \multirow{7}{*}{$\begin{array}{l}\text { Group } C: \\
\text { Add to complete the regimen and when medicines from Group } A \\
\text { and B cannot be used }\end{array}$} & ethambutol $(E M B / E)$ \\
\hline & delamanid $(D L M)$ \\
\hline & pyrazinamide $(P Z M / Z)$ \\
\hline & imipenem-cilastatin (IPM-CLN) or meropenem (MPM) \\
\hline & amikacin $(A M)$ or streptomycin $(S M / S)$ \\
\hline & ethionamide (ETO) or prothionamide (PTO) \\
\hline & p-aminosalicylic acid $(P A S)$ \\
\hline
\end{tabular}

Group of drugs used to treat MDR-TB

Group A consists of "priority" drugs (all three should be included in the treatment schedule).

Group B is represented by "companion" drugs (include at least one, if not both in the schedule).

Group C consists of "supplement" medications if group A and B does not provide at least 4 unused medicines with demonstrated sensitivity [24].

Group A.

Fluoroquinolones $(Q)$

Despite the changes in the therapeutic guidelines, quinolones continue to represent a major class of drugs used for the treatment of DR-TB. Although the anti-TB action is defined for several class representants, the current guidelines take into account as components of group A only recent generation of fluoroquinolones, such as levofloxacin (Lfx) and moxifloxacin (Mfx), drugs with better prognostic value [25]. They have a good bactericidal action by inhibiting bacterial DNA-gyrase with role in cellular replication, and moxifloxacin is considered to have a significant sterilizing action, which may shortened the treatment duration. Fluoroquinolones show cross-resistance within the class components [26]. Resistance to fluoroquinolones (along with $\mathrm{H}$ and $\mathrm{R}$ resistance) defines the "extreme" form of the disease, currently known as extensively drug-resistant TB (XDR-TB), which had, until recently, very limited chances to cure. They should be administered throughout the entire duration of the treatment. The frequency of severe adverse reactions is estimated at $2.9 \%$ for moxifloxacin and $4.1 \%$ for levofloxacin. Digestive and central nervous manifestations rarely interfere with the therapeutic course. Fluoroquinolones are known to prolong the QT interval, which may increase the risk of severe heart rhythm disturbances, more common in Mfx administration, especially if bedaquiline and clofazimine are associated. Cardiac monitoring is recommended when drugs that prolong the QT interval are used [27]. Bedaquiline $(B d q)$

It represents a new synthetized drug, the first in decades, specifically developed for the treatment of
DR-TB. Bedaquiline is a diarylquinoline with selective action on mycobacteria and irrelevant on other germs. It inhibits mycobacterial ATP - synthetase and induces intracellular ATP depletion.

Bedaquiline is active on various bacterial populations on strains that are susceptible or resistant to currently available anti-TB drugs.

It has a good bactericidal action on germs in active multiplication. The early bactericidal effect seems proportional with the administered dose. It can also act on germs with slow multiplication, intermittent or dormant; it also expresses a sterilizing action. Bedaquiline has a long terminal elimination halflife in plasma, of 5.5 months, a feature that is also encountered in clofazimine, another lipophilic antiTB drug. Due to this remarkable effect, along with the sterilizing action, it was possible to shorten the duration of the current therapeutic regimens from 18 - 24 months to 9 - 12 months [28]. Bedaquiline is associated with a low rate of spontaneous occurrence of resistant mutants of 1 out of $10^{7}-10^{8}$, similar to that of rifampicin, with a close profile. Except for the possible cross-resistance with clofazimine, the phenomenon does not concern other anti-TB drugs. Because it has been used on a large number of patients, currently, the role in the treatment schedule, the duration and rhythm of administration and the adverse reactions are well-known.

Bedaquiline is considered, by inclusion in the group A of drugs for DR-TB, alongside with quinolones and linezolid, as a priority in the long-term treatment of DR-TB.

It is generally well tolerated, with a risk of serious adverse reactions of $2.4 \%$ (compared with the linezolide of $17.2 \%$ ).

Some reactions are more common (dyspepsia, arthralgia, headache), while some are less frequent (hepatic cytolysis, hyperuricemia). Bedaquilin may produce QT interval prolongation, which can be associated with potentially severe arrhythmia as the torsades de pointes. The risk is significant when the drug it is associated with clofazimine and moxifloxacin [28, 29]. 
Linezolid ( Lzd)

It is a protein synthesis inhibitor working by suppressing bacterial protein production. The main use of linezolid in clinical practice is for treating the severe infections with aerobic MDR Gram-positive bacteria and the treatment of DR-TB.

Linezolid has a good bactericidal action on rapid multiplication bacteria and a moderate sterilizing action on germs with slow and intermittent multiplication rate. It should be administered during the entire period of treatment, but administration may be interrupted if severe side effects appear, related to mitochondrial toxicity. The drug may induce myelo-suppression (anaemia, leukopenia, thrombocytopenia, pancytopenia), peripheral and optic neuropathy, lactic acidosis, hence the need for careful monitoring. The frequency of severe adverse reactions decreases significantly with the reduction of the dose, currently of $600 \mathrm{mg}$ daily. Group B [30-32]:

Clofazimine ( $\mathrm{Cfz}$ )

It is a riminophenazine, primary used to treat leprosy. The mechanism of action is unclear, apparently through the intracellular accumulation of oxidant radicals. The bactericidal and possibly sterilizing effects were considered relevant enough for the substance to be included in Group B of drugs that should be associated with Group A in treatment of DR-TB. The long terminal elimination half-life in plasma, of 70 days, made possible to include clofazimine in the short-term scheme recommended by WHO (Bangladesh regimen). Severe adverse reactions are relatively rare $(3.6 \%)$, the prolongation of the QT interval may require interruption of drug administration. More common side effects are cutaneous, such as pink to brownish skin pigmentation, photosensitivity, ichthyosis [29, 30, 33].

Cycloserine (Cs)

Cycloserine is a D-alanine analogue. It works as a bacteriostatic by inhibiting mycobacterial cell wall synthesis. Cycloserine is restricted for use only against MDR and XDR strains of M. tuberculosis, as member of group B of anti-TB drugs in the last WHO guidelines. The important side effects (depression, suicide, psychosis, convulsions) may limit the use of this drug [28].

\section{Group C:}

It includes all other drugs that can be used in addition to the treatment schedule if one or more Group A and $\mathrm{B}$ agents cannot be used for various reasons (intolerance, contraindications, side effects, proven resistance and lack of access).

Group positioning expresses the expected benefit/risk ratio and implicitly imposes the order of choice.

Etambutol, pirazinamide, and streptomycin are line first medications, which are constantly used in the standard regimens for susceptible TB cases, but are also useful in individualized schedules after the sensitivity testing proven by the antibiogram.
Amikacin, structurally an aminoglycoside, is the only injectable second line drug which is still considered useful in the treatment of MDR-TB, because relevant statistics suggest that other injectable drugs that were largely previously used, such as kanamycin and capreomycin are associated with less favourable outcomes and consequently, are no longer recommended. Ethionamide/protionamide and $P A S$, as bacteriostatics with tolerance problems, are still useful and occasionally used to supplement standard treatment schedules.

Delamanid

It is a nitroimidazole, and like bedaquiline, it is a new anti-TB drug that has emerged after decades of less therapeutic relevance. It acts as pro-drug through active metabolites which inhibit the synthesis of mycolic acids from the mycobacterial wall structure.

Delamanid is credited with bactericidal action, but also sterilizing effect, and there are hopes to become the next "leading-drug". At least for the time being, studies have not shown a major therapeutic impact of Delamanid's in actual schedules and for this reason it's currently positioned in Group C. It is well-tolerated and it can also induce QT interval prolongation [31, 34, 35].

Carbapenems

Meropenem, imipenem and other carbapenems have demonstrated some anti-TB activity in therapeutic associations.

Imipenem-cilastin and meropenem-clavulanate may be associated with other anti-TB drugs in the situation of limited resources, hence the positioning in Group C. A disadvantage of carbapenems is the need for fractional administration (2 - 3 times/daily), which limits their use in ambulatory conditions [36].

The current review included to discuss only the recommended WHO medication guidelines, according with "Consolidated guidelines on drug-resistant tuberculosis treatment", published in 2019.

The agents under evaluation are much more numerous and the future will bring new insights. However, some trends are obvious. Injectable drugs are no longer perceived as priority drugs and the preference for oral medicines is obvious. The tendency to standardize the treatment regimens used in the treatment of DR-TB it is increasing. Fluoroquinolones, bedaquiline and linezolid are priority drugs.

Most regimens should initially include four drugs (for a 6 months period) and then three drugs regimen until the end of the treatment, which usually lasts for 18 - 20 months.

There are ongoing evaluations of short-term schedules of 9 - 12 months, but the results are still pending [32].

\section{Conclusions}

TB endemic has a long history. Bacteriological, imagistic and etiological diagnoses were developed relative recently (1882, 1895 and 1943). 
Standardization of treatment for TB sensitive cases developed in decades, but the disease is far from being eradicated. The phenomenon of resistance to antibiotics has emerged from the very beginning and currently represents a major risk for the effectiveness of standard therapy. For a while, TB treatment of cases with resistant strains was not a priority. The conceptual and institutional effort to fight this type of disease was initiated 20 years ago. Establishing the most effective treatment schedules is a complex process and the universal access to needed drugs is not fast enough. The latest WHO guidelines should be a real "game-changer".

The Romanian experience has been connected with the international developments. Patient assistance is partially reliant upon projects with external funding, usually based on a cohort system (number of defined cases); also, the existing structure of the Romanian health care system, including the reimbursement mechanisms, are not very helpful in addressing the issue [37].

There are significant differences registered between the therapeutic successes rates of those treated through international funded projects $(60-75 \%)$ compared to those treated in the National Program (20 - 30\%). This situation has raised constantly difficult ethical problems.

The actual Romanian legislation doesn't allow the extent use of medicines "off label" for TB patients, and this needs to be under scrutiny for administrative reforms [38]. Recently, most of MDR-TB drugs were included in the list $\mathrm{C} 2$ and centralized procured.

All of the above highlights why tuberculosis treatment is more of a legal, administrative, financial, and logistics arrangement, rather than a therapeutic one. The eradication of the disease (defined as one case per million inhabitants) seems not to be targeted in the near future.

\section{Conflict of interest}

The authors declare no conflict of interest.

\section{References}

1. Global Tuberculosis Report $2018^{\circledR}$ World Health Organization 2018.

2. History of TB drugs - PAS, Streptomycin, Waksman, www.TBfacts.org.

3. Marshall Geoffrey (chairman of the Committee), Streptomycin treatment of pulmonary tuberculosis. Br Med J., 1948; ii: 769-782.

4. Kerantzas CA, Jacobs WRJr, Origins of combination therapy for tuberculosis: lessons for future antimicrobial development and application. mbio.asm.org, 2017; 8(2): e01586-16: 1-10.

5. Treatment of pulmonary tuberculosis with paraaminosalicylic acid and streptomycin, Preliminary report, Para-Aminosalicylic Acid and Streptomycin. Br Med J., 1949; 1521.
6. Marshall Geoffrey (chairman of the Committee), The treatment of pulmonary Tuberculosis with Isoniazid: An Interim Report to the Medical Research Council by Their Tuberculosis Chemotherapy Trials Committee. Br Med J., 1952; 2(4787): 735-746.

7. Fox W, Ellard GA, Mitchison DA, Studies on the treatment of tuberculosis undertaken by the British Medical Research Council Tuberculosis Units, 19461986, with relevant subsequent publications. Int J Tuberc Lung Dis., 1999; 3(10Suppl.2): S231-S279.

8. Arghir OC, Alves Pereira PM, Rașcu A, Dantes E, Borgazi E, Iliescu DM, Oțelea MR, Cambrea SC, The impact of migrant tuberculosis on the chimioresistance pattern of antituberculosis drugs in a low burden tuberculosis European country. Farmacia, 2018; 66(3): 537-540.

9. Ianosi ES, Dantes E, Csipor A, Szathmary M, Socaci A, Rusu E, Nemes RM, Enhancing Education for Smoking Preventing and Smoking Cessation in Medical Personnel. A measure for a better health. Rev Chim (Bucharest), 2018; 69(10): 2725-2727.

10. Pyle M, Relative number of resistant tubercle bacilli in sputa of patients before and during treatment with streptomycin. Proc Staff Meet Mayo Clin., 1947; 22(21): 465-473.

11. David HL, Probability distribution of drug-resistant mutants in unselected populations of $M$. tuberculosis. Appl Microbiol., 1970; 20(5): 810-814.

12. Marica C, Didilescu C, Spânu V, Galie N, Pulmonary tuberculosis with chemorezistant germs, Ed. Tehnică Buc., 2001; 16-24, (available in Romanian).

13. Nolan CM, Williams DL, Cave MD, Eisenach KD, el-Hajj H, Hooton TM, Thompson RL, Goldberg $\mathrm{SV}$, Evolution of rifampicin resistance in human immunodeficiency virus-associated tuberculosis. Am J Resp Cr Care Med., 1995; 152(3): 1067-1071.

14. Pablo-Mendez A, Raviglione MC, Laszlo A, Binkin N, Rieder HL, Bustreo F, Cohn DL, Lambregts-van Weezenbeek CS, Kim SJ, Chaulet P, Nunn P, Global surveillance for antituberculosis-drug resistance, 19941997. World Health Organization-International Union against Tuberculosis and Lung Disease Working Group on Anti-Tuberculosis Drug Resistance Surveillance. $N$ Engl J Med., 1998; 338(23): 1641-1649.

15. Cioran N, Popescu G, Mihailescu L, Didilescu C, Cocei H, Chiotan D, TB among prisoners in Romania, 2009-2011. Eur Resp J., 2013; 42(Suppl.57): P4472 (4039).

16. Small PM, Moss A, Molecular epidemiology and the new tuberculosis. Infect Ag Dis., 1993; 2(3): 132-138.

17. Rattan A, Kalia A, Ahmad N, Multidrug-resistant $M$. tuberculosis: molecular perspectives. Emerging Infect Dis., 1998; 4(2): 195-209.

18. Stratan E, Ţurcan N, Crudu V, Romancenco R, Cotelea T, Niţulescu GM, Chiriţă C, Moruşciag L, Biological evaluation of new 2-phenethylbenzoyl thiourea derivatives as antituberculosis agents. Farmacia, 2018; 66(1): 97-106.

19. Davis J, Inactivation of antibiotics and the dissemination of resistance genes. Science, 1994; 264(5157): 375382.

20. Nemeș RM, Duceac LD, Vasincu EG, Agop M, Postolache P, On the implications of the biological 
systems fractal morpho functional structure of the lung. UPB Sci Bull A., 2015; 77(4): 263-272.

21. Crofton J, The prevention and management of drug resistant tuberculosis. Bull Int Union Tuberc Lung Dis., 1987; 62: 6-11.

22. Sir Crofton J, Guidelines for the management of drug-resistant tuberculosis. World Health Organization, 1997.

23. Guidelines for the programmatic management of drugresistant tuberculosis. World Health Organization, 2006; $1^{\text {st }}$ Ed.: 38-52.

24. Rapid Communication: Key changes to treatment of multidrug- and rifampicin-resistant tuberculosis (MDR/RR-TB). World Health Organization, 2018.

25. Quana D, Nagalingama G, Paynec R, Triccas JA, New tuberculosis drug leads from naturally occurring compounds. Int J Infect Dis., 2017; 56: 212-220.

26. Hyun Lee, Soohyun Ahn, Na Young Hwang, O Jung Kwon, Hee Jae Huh, Nam Yong Lee, Chang-Ki Kim, Won-Jung Koha, Limited effect of later-generation fluoroquinolones in the treatment of Ofloxacin-resistant and Moxifloxacin-susceptible Multidrug-Resistant Tuberculosis. Antimicrob Agents Chemother., 2018; 62(2): e01784-17: 1-31.

27. Mohammad Asif, An overview on fluoroquinolone drugs for the treatment of tubercular infection. Int $J$ Biosen Bioelectron., 2017; 2(1): 33-36.

28. Companion handbook to the WHO guidelines for the programmatic management of drug-resistant tuberculosis. World Health Organization, 2014.

29. Cholo MC, Mothiba MT, Fourie B, Anderson R, Mechanisms of action and therapeutic efficacies of the lipophilic antimycobacterial agents clofazimine and bedaquiline. J Antimicrob Chemother., 2017; 72(2): 338-353.
30. Migliori GB, Bothamley G, Duarte R, Rendon A, Tuberculosis. New and repurposed drugs ERS monographs, published by European Respiratory Society, 2018; 179-204.

31. Mafukidze A, Harausz E, Furin J, An update on repurposed medications for the treatment of drugresistant tuberculosis. Exp Rev Clin Pharmacol., 2016; 1-11.

32. Seyed Mohammad Reza Hashemian, Tayebeh Farhadi, Mojdeh Ganjparvar, Linezolid: a review of its properties, function, and use in critical care. Drug Des Develop Ther., 2018; 12: 1759-1767.

33. O'Donnell MR, Padayatchi N, Metcalfe JZ, Elucidating the role of clofazimine for the treatment of tuberculosis. Int J Tuberc Lung Dis., 2016; 20(12): 52-57.

34. WHO position statement on the use of delamanid for multidrug-resistant tuberculosis. World Health Organization, 2018.

35. WHO consolidated guidelines on drug-resistant tuberculosis treatment. World Health Organization, 2019.

36. Tiberi S, Munoz-Torrico M, Duarte R, Dalcolmo M, D'Ambrosio L, Migliori GB, New drugs and perspectives for new anti-tuberculosis regimens. Pulmonology, 2018; 24(2): 86-98.

37. Radu CP, Chiriac DN, Vladescu C, Changing Patient Classification System for Hospital Reimbursement in Romania. Croat Med J., 2010; 51(3): 250-258.

38. Vladescu C, Astarastoae V, Scintee SG, A Health System Focused on Citizen's Needs. Romania. Hospital Services, Primary Health Care and Human Resources. Solutions. Revista Romana de Bioetica, 2010; 8(4): 89-99. 